Ünveren, I. T. (2018). Yazma becerisi etkinliklerinde algısal öğrenme ve drama ilişkisi. Ana Dili Eğitimi Dergisi, $6(3), 652-669$.

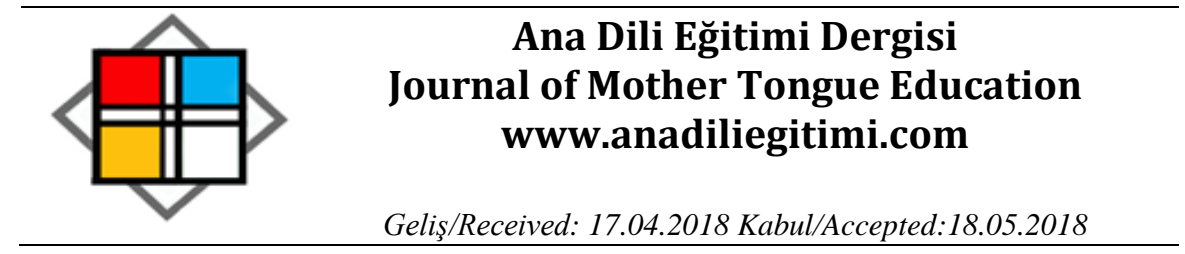

\title{
Yazma Becerisi Etkinliklerinde Algısal Öğrenme ve Drama İlişkisi
}

\author{
Işılay TERZIOĞLU ÜNVEREN*
}

Öz

Bu çalışmada, yazma becerisi etkinliklerinde algısal öğrenme ve drama ilişkisini, algı çeşitliliği, anlatım zenginliği ve kullanılan kelime sayısı yönleriyle belirlemek amaçlanmıştır. Çalışma, gerçek deneme modellerinden ön-test son-test kontrol gruplu model ile desenlenmiştir. Araştırmanın çalışma grubunu 2017/2018 eğitim öğretim yılında Ankara ili Altındağ ilçesi Peyamitepe Şehit Mehmet Kocakaya illkokulu'nda öğrenim gören 51 üçüncü sınıf öğrencisi oluşturmaktadır. Veri toplama aracı olarak yazııı anlatım kâğıdı kullanılmıştır ve veriler, içerik analizi tekniğinden yararlanılarak çözümlenmiştir. Araştırmanın verilerinden hareketle yazma becerisinde drama ve algısal öğrenmenin ilişkili olduğu görülmüştür. Drama ve algısal öğrenmenin birlikte yer aldığı yazma becerisi etkinliklerinde algıda çeşitlilik, anlatımda zenginlik ve kullanılan kelime sayısında artı̧̧ olduğu tespit edilmiştir.

Anahtar Kelimeler: Yazma becerisi, algısal öğrenme, drama.

Relationship between Perceptual Learning and Drama in Writing Skill Activities

\begin{abstract}
The purpose of this study was to determine the relationship between perceptual learning and drama, richness of perception, richness of expression, and the number of words used in writing skill activities. The study was designed as a pre-test post-test control group which is one type of quantitative research models. The study group of the study consisted of $513^{\text {rd }}$ grade students in the Peyamitepe Şehit Mehmet Kocakaya Elementary School in the Altındağ district of the Ankara province in the 2017/2018 academic year. Written expression paper was used as the data collection tool, and data were analyzed, using content analysis technique. It was seen that drama and perceptual learning were related in the writing ability. In the writing activities in which drama and perceptual learning occur together, richness of perception, richness of expression, and an increase in the number of words used were observed.
\end{abstract}

Keywords: Writing skill, perceptual learning, drama.

\section{Giriş}

Bireyin süreç içerisinde yaşantısını doğrudan etkileyen ve onda kalıcı davranış değişikliği oluşmasına zemin hazırlayan öğrenme zihinsel, psikolojik, dil, düşünce ve motivasyonla birlikte algı ve bellek gibi birçok unsurun bileşenlerinden oluşan organizasyonudur. Öğrenmenin oluşabilmesi için öğrenen ve öğreten olmak üzere iki unsura ihtiyaç vardır.

Öğrenmede ilk olarak dış uyarıcılar duyu organlarına ulaşır ve duyusal alıcılara aktarılır. Ardından kısa süreli belleğe geçiş yapar. Sonrasında tekrar işleme ve kodlama işlemleriyle uzun süreli

\footnotetext{
* Öğretmen, Peyamitepe Şehit Mehmet Kocakaya IIlkokulu, Ankara, isilayterzioglu@gmail.com
} 
belleğe aktarılır (Arı, 2010). Öğrenilen bilgiye ihtiyaç duyulduğunda uzun süreli bellekten geri çağırılır. Bu öğrenme sürecinde de görüldüğü üzere öğrenmeyi başlatan unsur, duyu organlarımızın dış uyarıcılarla etkileşiminden doğan algılamadır.

Algı ile öğrenme arasında çift yönlü bir ilişki vardır. Her ne kadar öğrenmenin başlaması için algı gerekse de algının olması için de ön yaşantılar gerekmektedir. Arı (2010) da algılamanın gerçekleşmesinde önceki öğrenmelerin belirleyici rol üstlendiğini belirtir. Yeni öğrenmeler, geçmiş öğrenmelerde edinilen bilgilerin üzerine inşa edilir. Böylece bir kavrama yönelik algılarımız çeşitlenerek genişler ya da değişime uğrar.

Algılama sürecini öğrenme ile birleştirdiğimizde öğrenme daha hızlı olur. Yazma etkinliklerini algı odaklı gerçekleştirdiğimizde öğretim daha etkili hale gelir. Beş duyunun da işin içine sokulduğu öğrenme yaşantılarıyla daha çok kelime ile daha zengin anlatım sağlanmış olur. Öğrenciler öğretimi söz konusu olan bir kavramı detaylandırıp, ön öğrenmeleriyle ilişkilendirerek yeni öğrenmeleri için basamak olarak hazır bulundurur.

Öğretimi planlarken öğrencilerin algılama düzeyleri iyi bilinmelidir. Öğrencilerin bulundukları yaş grubuna uygun olarak anlama ve algılama seviyeleri farklılaşır (Aytaş, 2008). Günümüzde pek çok bilimsel çalışma, eğitimde dramaya yer verilmesinin akademik başarıyı arttırdığı sonucuna ulaşmaktadır (Ulubey ve Toraman, 2015). Yazma, zihinsel süreçler sonucunda ortaya çıkan Türkçenin dört büyük beceri alanından en son ve en zor kazanılanıdır. Drama, yazma becerisini geliştirecek etkinliklerde çok duyulu yaşantılar sağlayarak var olan anlama ve algılama seviyesini yükseltmeye çalışır. Bu araştırmada ele alınan yaş grubu dokuz yaş civarıdır ve Nutku (1988)' ya göre yedi ile on iki yaş arasındaki çocukların drama etkinliklerinde arayış, bulgu ve yaratış vardır. Yazma etkinliklerinde yer alan drama, çocukların arama, bulma ve yaratma eylemlerini somut yaşantılarla destekleyerek öğretimin etkili olmasını sağlayacaktır. Öğrencileri, yazarken daha çok ve çeşitli kelime kullanmaya cesaretlendirerek benzetme, ilişkilendirme, tanımlama, örnekleme, tasvir etme gibi birtakım yazma becerilerinin gelişmesinin önünü açacaktır.

Alanyazın incelendiğinde, yazma becerisi etkinliklerinde algısal öğrenme ve drama ilişkisini konu alan bir çalışmaya rastlanmamıştır. Araştırma konusuna en yakın çalışma Aytaş (2013)'ın, yaratıcı dramanın algısal öğrenmedeki rolünü ortaya koyan araştırmasıdır. Birçok araştırmacı öğrenme stillerini çeşitli açılardan incelemişlerdir. Bunlardan bazıları (Beck, 2001; Demir, 2008; Şimşek, 2007; İnal, Büyükyavuz ve Tekin, 2015; Önder, 2012; Özkan; 2013), öğrenme stilleri başlığı altında algısal öğrenme stiline de yer vermiştir.

Dokuz ile on bir yaş aralığındaki öğrencilerin büyük çoğunluğunun algısal öğrenme stillerinden dokunsal öğrenmeyi tercih ettiği (Şimşek, 2007) göz önünde bulundurulursa dokunsal (bedensel) 
öğrenmeye en uygun yöntemlerden biri olan dramanın algısal öğrenme ile birlikte ele alınması gerekmektedir. Bu bağlamda araştırmada, ilkokul üçüncü sınıfta yazma becerisi etkinliklerinde algısal öğrenme ve dramanın ilişkisini ortaya koymak amaçlanmıştır. Bu amaca yönelik olarak araştırmada aşağıdaki sorulara cevap aranmıştır:

1. Dramanın yazma becerisi etkinliklerinde, öğretilen kavramı çeşitli duyularla algılamaya etkisi var mıdır?

2. Dramanın algısal öğrenmeyle birlikte yazma becerisi etkinliklerinde yazılı anlatımı zenginleştirmeye (benzetme, ilişki kurma, örnek verme, tanımlama ve tasvir etme vb.) etkisi var mıdır?

3. Dramanın algısal öğrenmeyle birlikte yazma becerisi etkinliklerinde kullanılan kelime sayısına etkisi var mıdır?

\section{Yazma Becerisi Etkinliklerinde Algısal Öğrenme ve Drama iliş̧kisi}

"Duyu, duyu organlarının getirmiş olduğu henüz işlenmemiş bilgidir. Algı, gelen bilgileri işleyerek belirli bir yapı ve organizasyona sokma işlemine verilen addır (Cüceloğlu, 2002: 136)." Bir başka deyişle algı dokunma, tatma, görme, koklama ve işitme duyularının elde ettiği verileri yorumlayıp anlamlandırma sürecidir (Aytaş, 2013). Forgus (1966) ise algıyı, organizmanın çevre hakkındaki bazı bilgileri elde edip bu bilgileri meydana çıkardığı bir süreç olarak görmektedir.

Algılarımız sayesinde çevremizi algılar ve anlamlandırırız. Algılamada esas olan ise duyumdur. "Duyum alıcı organların çevredeki enerjinin etkisi altında uyarılmasıyla ortaya çıkan nörofizyolojik süreçlere verilen addır (Cüceloğlu, 2002: 98)." Algılama yaparken etkileşime girdiğimiz varlıklara yönelik bilgileri duyum vasıtasıyla elde ederiz. Duyumu yani duymayı sağlayan ise beş duyumuzdur.

Duyularımız birbiriyle etkileşim halindedir (Aytaş, 2016). Bir nesneyi algılamaya yönelik belirgin bir duyu olsa bile diğer duyularımız da işin içine girmiş olur. Öyle ki burun ile dilin eş güdümlü çalıştığı kabul gören bir gerçektir (Demiray ve Köker, 2017). Limon denilince aklımıza tadı ile birlikte kokusu ve hatta rengi de gelmektedir. Başka bir örnek olarak zil denilince aklımıza sesi gelse de beraberinde şekilsel özellikleri de zihnimizde yer etmektedir.

Görme, işitme, tatma, koklama ve dokunma özelliklerine yönelik beş duyumuzun yanında İnceoğlu (2004), hissetmek kavramına da algılama sürecinde yer verir. Böylece algılama, olaylara ilişkin algımızın da dâhil edildiği sosyal ve psikolojik bir olgu olarak tanımlanmış olur.

Eğitim ve öğretim faaliyetlerinde algılama, merkezi bir konumda yer alır. Bir öğrenme stili olarak kabul gören algısal öğrenmede, duyu organları ile birlikte gözlemden yararlanılarak somut bilgi 
ve olgular kullanııır (Veznedaroğlu ve Oytun Özgür, 2005). Beş duyuya hitap edilerek çok yönlü öğretim sağlanır.

Algısal öğrenme ve düşünme, deneyim ve zengin yaşantılar sonucunda genişlemektedir (Forgus, 1966). Zengin yaşantılar ise birden çok duyunun işe koşulduğu eğitim uygulamaları ile gerçekleşir. Birçok duyuyu harekete geçirerek kalıcı izli davranış değişikliği oluşturan etkili öğretim yöntemlerinden olan drama, çeşitli durumların hazırlık yapmaksızın canlandırılmasıdır (Arıkan, 2011). Dramanın birçok tanımı yapılmakta ve kullanım amacına göre yaratıcı ve eğitici drama olarak sınıflandırılmaktadır. Adıgüzel (2006: 21) ise dramayı şu şekilde tanımlamaktadır:

"Eğitimde yaratıcı drama, herhangi bir konuyu doğaçlama, rol oynama gibi tekniklerden yararlanarak bir grupla veya grup üyelerinin birikimlerinden, yaşantılarından yola çıkarak canlandırmalar yapmaktır."

Drama, öğrenilen bilgilerin akıl ve hayal gücü süzgecinden geçirilmesini sağlar. Böylece çocuk, öğrendiği bilgileri zihninde yer eden çağrışımlara göre anlamlandırarak anlatır. Duygu ve düşüncelerinin farkına drama yoluyla varan çocuk, yaşamı beş duyusunu kullanarak algılar (Nuhoğlu ve Çakmakçı, 2007).

Drama uygulamaları, öğrencilerin mevcut bilgilerinin üstüne yeni bilgiler eklemelerine olanak tanır (Uşaklı, 2014). Drama, çocukların sahip oldukları kavram sayısını arttırarak düşüncelerini zenginleştirir (Yalçın ve Aytaş, 2012). Algılarımızla öğrenebildiğimize göre var olan algımız yeni öğrenmelerle değişir ya da genişler. Hem drama hem de algısal öğrenme, bir kavrama yönelik algının değiştirilebileceğine dair önemli bir kanıttır. Algısal öğrenme, tekrarlı uygulamalar aracılığıyla belirli bir algısal becerinin geliştirilmesi anlamını taşır (Özgen, 2004).

Drama uygulamaları sayesinde gelişen ve zenginleşen algıyı, ifade etme yollarından biri de yazıı anlatımdır. Yazma duygu, düşünce, hayal ve isteklerimizi ifade etme biçimlerinden biridir. Aynı zamanda çocukların bir kavram ile ilgili algısının ne düzeyde olduğunu görebileceğimiz bir araçtır. Yazma etkinliklerinde kâğıt ve kalemle baş başa kalan çocuk, söz konusu olan kavram ya da olaylarla ilgili mevcut algılamalarını kâğıda döker. Aytaş (2016) da bir konu hakkında etkili bir yazı yazmak için öncelikle o konu ile ilgili önceden kazanılmış algıya gereksinim olduğunu belirtmektedir. Sahip olduğumuz algı ve öğrenmeye dayalı olarak görüş belirtir, tanımlama ve tasvirde bulunuruz. Yazılı anlatım bu yönüyle öğrencilerin bir konu veya kavram hakkındaki algılarını ortaya çıkaran etkili bir araçtır. Sözlü anlatımın aksine yazılı anlatımda bilgilerin kalııılığı daha yüksektir. Bu durum da öğrencilerin şimdiki ve ilerideki algılamalarına ışık tutar.

Yazma etkinliklerinde drama ve algının bir başka önemli etkisi ise anlatım zenginliğidir. Drama, öğrencilerin yeni kavramlar öğrenmesini sağlar (Yalçın ve Aytaş, 2012). Bir nesneye yönelik var olan 
algı, drama etkinlikleri aracılığıyla genişler. Bu da öğrencilerin yazılı anlatım çalışmalarında mevcut kelime sayısı ve çeşidini arttırmaları ile kendini gösterir. Aynı zamanda bu nesnenin farklı duyularla algılanan özellikleri de dile getirilmiş olur.

Ungan (2007) ise yazmayı, bir bilgi edinme şekli olarak görmektedir. Ona göre yazma, algı ve öğrenme gibi dış dünyadan veriler elde etme yöntemlerinden biridir ve onu, bu kavramlardan ayrı düşünmemek gerekir.

Görüldüğü gibi algı, drama ve yazma kavramları birbiri ile iç içe geçmiştir. Yazma etkinliklerinde algısal öğrenmenin gereği olan beş duyuya yönelik drama uygulamaları ile etkili bir eğitim öğretim sağlanabilecektir.

\section{Algı ve Drama}

Algı, öğrenme ve düşünme alt kümelerini kapsayan bir üst kümedir (Forgus, 1966). Algısal öğrenme ise, algılanan uyaranın anlamlandırııı tanınmasından sonra ona ait başka bilgilerin de kolaylıkla öğrenilmesidir (Terry, 2012).

Algısal öğrenme, hareket ve etkileşimi bünyesinde barındıran drama sayesinde gerçekleşir. Çok yönlü etkinlikleri bünyesinde barındıran öğretim yöntemlerinden biri olan drama, eğitimin çok duyulu yapılması anlayışıla hareket eder. Drama sınıflarında, daha geleneksel sınıfların aksine kavramların hareket ve yaratıcılık içerisinde araştırılması gibi önemli unsurlar vardır. Dramada, öğrencilerin ele aldıkları konuya uygun davranarak çalıştıkları materyallere kendilerini kaptırmaları gerekir (Poulsen, 1998).

Dramadaki rol oynama tekniği sayesinde öğrenciler başka bir kimliğe bürünerek kavramlara ya da nesnelere korkusuzca yaklaşıp özgür bir ortamda duyu organlarıyla etkileşimde bulunabilmektedirler. Drama etkinlikleri aracılığı ile öğrenciler, nesnelere karşı çeşitli algılar edinerek aralarındaki ayrımı görebilmektedirler. Dramada duyu çalışmalarına yer veren Nuhoğlu ve Çakmakçı (2007) da dramanın ekşi, acı gibi birbirine yakın duygu ifadelerinde detayların fakına varmayı sağladığını belirtmişlerdir. Tüm bunlar gösteriyor ki drama duygu, düşünce ve davranış değişikliği yaratabilecek güçlü bir araçtır (Bowell ve Heap, 2001).

\section{Yöntem}

\section{Araştırmanın Modeli}

Tesadüfi yöntemle seçilen iki grup üzerinden yapılan bu araştırmada deneme modelleri arasından en yaygın olan ön test, son test ve kontrol grubu model olarak kullanılmıştır. 


\section{Örneklem / Araştırma Grubu}

Araştırmanın evrenini 2017-2018 eğitim öğretim yılında Ankara ilindeki ilkokulların üçüncü sınıflarında öğrenim gören çocuklar oluşturmaktadır.

Araştırmanın örneklemini, 2017-2018 eğitim-öğretim yılında Ankara ili Altındağ ilçesi Peyamitepe Şehit Mehmet Kocakaya İlkokulu'ndan tesadüfi yöntemle seçilen iki grup oluşturmaktadır. Araştırmanın çalışma grubunu 3/A (deney grubu) ve 3/C (kontrol grubu) sınıflarında öğrenim gören 34 erkek, 17 kız olmak üzere toplam 51 öğrenci (25 kontrol, 26 deney) oluşturmuştur.

\section{Veri Toplama Araçları}

Veri toplama aracı olarak yazılı anlatım kâğıdı kullanılmıştır. Bu araç, öğrencilerin kavramlar hakkındaki algılarını ortaya çıkarmak amacıyla araştırmacı tarafından Türkçe eğitimi alanından bir uzmanın görüşüne başvurularak hazırlanmıştır. Araç, ilk kısımda uygulama tarihi ile öğrencilere ait cinsiyet, rumuz, sınıf ve şube bilgilerini ortaya çıkaracak alanlardan oluşmaktadır. Takip eden kısımda ise "Yazılı Anlatım Kâğıdı" başlığı altında yazılı anlatımda bulunulabilecek satırlara yer vermektedir.

\section{İşlem / Verilerin Toplanması}

Bu çalışmada, deney grubundaki ilkokul üçüncü sınıfa devam eden 26 öğrencinin yazılı anlatımlarında zil, taş, limon, gül ve bardak kavramlarına yönelik algıları belirlenmeye çalışılmıştır. Terry (2012), algısal öğrenmede öğrenciler tarafından bilinen uyaranları kullanmanın yeni öğrenmeleri olumlu etkileyeceğini belirtir. Bu sebeple drama uygulamaları için, her öğrencinin günlük yaşantısında en az bir defa duyu organlarından herhangi biri tarafından temasa geçmiş olabileceği varsayılan kavramlar arasından beş varlık seçilmiştir. Benzer şekilde çalışmada yer alan öğrenciler ilkokul üçüncü sınıfa devam eden dokuz yaşlarındaki çocuklardır. Yedi ile on iki yaş arasındaki çocuklar somut işlemler dönemindedir ve duyu organlarıyla algılayamadıklarıyla işlem yapamazlar (Bacanlı, 2014). Somut varlıklardan seçilen bu kavramların algılanma biçimini doğrudan sağlayan baskın birer hedef duyu belirlenmiştir. Bu hedef duyular zil için işitme, taş için dokunma, limon için tatma, gül için koklama ve bardak için görmedir. Bunların dışında anlatımda yer verilen tüm duyular da dikkate alınmıştır.

Öğrenciler, bahsi geçen kavramlara yönelik uygulama öncesi yaşantılarında beş duyu aracılı̆̆ı ile edindikleri bilgileri yazılı olarak ifade etmişlerdir. Deney grubu ile bu kavramlara yönelik, hedef duyu odaklı beş farklı drama oturumu gerçekleşmiştir. Oturumlar haftada bir ders saati (40 dk.) olmak üzere beş hafta sürmüştür. Kontrol grubu ile hiçbir etkinlik yapılmamış, sınıf öğretmenleri eşliğinde programın ön gördüğü eğitim öğretim faaliyetlerini sürdürmüşlerdir. Beş haftanın sonunda deney ve kontrol grubundaki tüm öğrencilerden aynı kavramlara yönelik düşüncelerini tekrar yazmaları istenmiş̧ir. 
Deney grubu ile yürütülen drama uygulamalarının başında öğrencilerin gözleri kapatılmış ve nesnelere yönelik ilk algılarının görme dışında gerçekleşmesi sağlanmıştır. Zil kavramını esas alan oturumda çeşitli zil sesleri dinlettirilerek hangi ses kaynağına ait olduğu tahmin ettirilmiştir. Limon tattırılmış, taşa dokundurulmuş, bardak görselleri sunulmuş, gül ise koklatılmıştır. Böylece dramatik kurgu içerisinde yer alan bu varlıklarla birinci elden temasa geçip, rol içinde günlük hayatlarında kullandıkları ya da kullanabilecekleri durumları canlandırmaları sağlanmıştır.

\section{Verilerin Analizi}

Veriler, içerik analizi yöntemiyle analiz edilmiştir. İfadelerin açık uçlu olması ve anlatımda duyu ifadelerine yer verme ve anlatım zenginliği gibi değişkenlere bakılacağı için bu teknik tercih edilmiştir. Her kavram için öğrencilerin yazılarından seçilen ve sık kullanılan duyu ifadeleri kodlanmıştır. Bu kodlar kategorileştirilmiştir. Oluşturulan kategoriler esas alınarak yargıya varılmıştır.

Güvenirliği sağlamak için iki farklı alan uzmanı ayrı ayrı kodlamalar yapmış ve Miles-Huberman modelinin görüş birliği kat sayısı[üzerinde görüş birliği sağlanan terim sayısı/(üzerinde görüş birliği sağlanan terim sayısı + üzerinde görüş birliği bulunmayan terim sayısı) $\times 100]$ esas alınmıştır (Baltacı, 2017). Buna göre güvenirliğin (kodlayıcılar arası görüş birliği) \% 88 olduğu tespit edilmiştir. Ayrıca deney grubuyla araştırma sonuçları paylaşılıp geri dönütler alınarak güvenirlik arttırılmaya çalışılmıştır. Çalışmanın geçerliği için aktarılabilirlik, güvenilebilirlik, onaylanabilirlik ile inandırıcılık yönünden kuvvetli olmasına özen gösterilmiştir (Guba ve Lincoln, 1982; Akt. Başkale, 2016).

\section{Bulgular}

Deney ve kontrol grubumuzun toplam mevcudu 51 kişi olup, bunlardan 26 öğrencinin (deney grubu) algılama düzeylerinin gelişimi takip edilmiş ve bu yönde bulgulara ulaşılmıştır. Buna göre bu bölüm, araştırma sorularına yönelik olarak üç başlık altında ele alınmıştır.

Dramanın Yazma Becerisi Etkinliklerinde, Öğretilen Kavramı Çeşitli Duyularla Algılamaya Etkisine Yönelik Bulgular

Öğrencilerin seçili kavramlara yönelik kod ifadeleri belirlenmiştir. Deney (f1) ile kontrol (f2) grubu olmak üzere iki grup halinde ön ve son testte yazdıkları ifadelerde bu kodlara yer verme sıklıkları not edilmiştir. Elde edilen veriler tablolaştırılmıştır. 
Tablo 1. Zil kavramını algılamayla ilgili uygulama öncesi ve sonrasına yönelik bulgular

\begin{tabular}{|c|c|c|c|c|c|}
\hline Duyular & Kod & $f 2.1$ & $f 1.1$ & $f 2.2$ & $f 1.2$ \\
\hline \multirow[t]{4}{*}{ Görme } & Çan & & & & \\
\hline & Yuvarlak & 6 & 10 & 7 & 23 \\
\hline & Kare & & & & \\
\hline & Demir & & & & \\
\hline \multirow[t]{7}{*}{ İşitme } & Teneffüs & 20 & 22 & 23 & 23 \\
\hline & Çalmak & & & & \\
\hline & Okul zili & & & & \\
\hline & Alarm & & & & \\
\hline & Ses & & & & \\
\hline & Duymak & & & & \\
\hline & Kulak & & & & \\
\hline Koklama & Kokusu yok. & 0 & 0 & 0 & 13 \\
\hline Tatma & Tadı yok. & 0 & 0 & 0 & 15 \\
\hline \multirow[t]{5}{*}{ Dokunma } & Ellemek & 9 & 5 & 8 & 11 \\
\hline & Tıklatmak & & & & \\
\hline & Sallamak & & & & \\
\hline & Basmak & & & & \\
\hline & El zili & & & & \\
\hline Toplam & & 35 & 37 & 38 & 85 \\
\hline
\end{tabular}

Not. f1.1: deney grubu ön test kod kullanım sıklığı, f1.2: deney grubu son test kod kullanım sıklığı, $f 2.1$ : kontrol grubu ön test kod kullanım sıklığı, f2.2: kontrol grubu son test kod kullanım sıklığı

Tablo 1'de görüldüğü üzere öğrencilerin zile yönelik algıları beş kategori altında toplam on sekiz kodda toplanmıştır. Deney grubunda tüm duyulardaki algılamada artış yaşanmıştır $(f 1.2-f 1.1=48)$. En fazla artış tatmada yaşanırken ez az artış ise işitme duyusunda olmuştur.

Kontrol grubunda da az miktarda artış yaşanmıştır ( 2 2.2- $f 2.1=3)$. En çok artış işitmede olurken dokunma duyusunda azalma söz konusu olmuştur.

Deney grubundaki öğrencilerin drama çalışmasının etkisinde kalarak, zili anlatan yazılarında kullandıkları, algılarını ortaya çıkaran ifadelerden örnekler aşağıda sunulmuştur:

U: “Kapı zili, bisiklet zili, okul zili gibi türleri vardır."

H: “... canlandırma, deri, oyun, el, drama çalışması, kapı, merdiven, boya, ev, beyaz, demir, parmak, tatsız, ...". 
H. G. : "Birisi kazandığında hemen zile basar, din din din."

Tablo 2. Taş kavramını algılamayla ilgili uygulama öncesi ve sonrasına yönelik bulgular

\begin{tabular}{|c|c|c|c|c|c|}
\hline Duyular & Kod & $f 2.1$ & $f 1.1$ & $f 2.2$ & $f 1.2$ \\
\hline \multicolumn{6}{|l|}{ Görme } \\
\hline & Küçük & 12 & 12 & 14 & 19 \\
\hline & Büyük & & & & \\
\hline & Şekil & & & & \\
\hline & Renk & & & & \\
\hline İşitme & Sesi yok. & 0 & 0 & 0 & 0 \\
\hline Koklama & Kokusu yok. & 0 & 0 & 0 & 4 \\
\hline \multirow[t]{2}{*}{ Tatma } & Tadı yok. & 0 & 0 & 2 & 5 \\
\hline & Yenmez & & & & \\
\hline \multirow[t]{6}{*}{ Dokunma } & Kaygan & 9 & 15 & 12 & 20 \\
\hline & Pürüzlü/süz & & & & \\
\hline & Sert & & & & \\
\hline & Kırılgan & & & & \\
\hline & Esnek & & & & \\
\hline & Kırılmaz & & & & \\
\hline Toplam & & 21 & 27 & 28 & 48 \\
\hline
\end{tabular}

Not. f1.1: deney grubu ön test kod kullanım sıklığı, f1.2: deney grubu son test kod kullanım sıklığı, $f 2.1$ : kontrol grubu ön test kod kullanım sıklığı, f2.2: kontrol grubu son test kod kullanım sıklığı

Tablo 2'de görüldüğü üzere öğrencilerin taşa yönelik algıları beş kategori altında toplam on dört koddan oluşmaktadır. Deney grubunda tüm duyulardaki algılamada artış yaşanmıştır $(f 1.2-f$ 1.1=21). En fazla artış görmede yaşanırken artışın yaşanmadığı duyu, işitme duyusu olmuştur. .

Kontrol grubunda da az miktarda artış yaşanmıştır (f2.2- $f 2.1=7)$. En çok artış dokunmada olurken işitme duyusunda bir değişim yaşanmamış, bu yönde algı kazanılmamıştır.

Deney grubundaki öğrencilerin drama çalışmasının etkisinde kalarak taşı ele alan yazılarında algılarını ortaya çıkaran ifadelerden bazıları aşağıda sunulmuştur:

A: "Rengi değişik, ağırdır."

M: “Asfalt yollarda, deniz ve dere kenarlarında bulunabilir."

M: "Ucu sivridir."

B: "Oyun oynanır, eskiden un yapmak için kullanılır."

U: "Katı ve sert, deri ile anlaşılır." 
A: "Kırılır, elimizle anlarız."

Y: "Kokusu yoktur, yenmez, katıdır."

Tablo 3. Limon kavramını algılamayla ilgili uygulama öncesi ve sonrasına yönelik bulgular

\begin{tabular}{|c|c|c|c|c|c|}
\hline Duyular & Kod & $f 2.1$ & $f 1.1$ & $f 2.2$ & $f 1.2$ \\
\hline \multirow[t]{4}{*}{ Görme } & Sarı & & & & \\
\hline & Sulu & 22 & 14 & 16 & 25 \\
\hline & Çekirdekli & & & & \\
\hline & Kabuklu & & & & \\
\hline İşitme & Sesi yok. & 0 & 0 & 0 & 4 \\
\hline Koklama & Kokusu var. & 0 & 0 & 0 & 10 \\
\hline \multirow[t]{3}{*}{ Tatma } & Ekşi & 22 & 17 & 19 & 24 \\
\hline & $\mathrm{ACl}$ & & & & \\
\hline & Tatlı & & & & \\
\hline \multirow[t]{3}{*}{ Dokunma } & Sıkmak & 0 & 5 & 9 & 5 \\
\hline & Pürüzlü & & & & \\
\hline & Kesmek & & & & \\
\hline Toplam & & 44 & 36 & 44 & 68 \\
\hline
\end{tabular}

Not. f1.1: deney grubu ön test kod kullanım sıkığı, f1.2: deney grubu son test kod kullanım sıklığı, f2.1: kontrol grubu ön test kod kullanım sıklğı, f2.2: kontrol grubu son test kod kullanım sıklı̆ı

Tablo 3'te görüldüğü üzere öğrencilerin limona yönelik algıları beş kategori altında toplam on iki koddan oluşmaktadır. Deney grubunda tüm duyulardaki algılamada artış yaşanmıştır (f1.2- $f 1.1=32$ ). En fazla artış görmede yaşanırken dokunma duyusunda bir değişim olmamıştır.

Kontrol grubunda toplam duyu sayısında değişim yaşanmazken görme ve tatmada azalma, dokunmada artış görülmüştür. İşitmeye dönük bir bulguya ise ön ve son testte rastlanmamıştır.

Deney grubundaki öğrencilerin drama çalışmasının etkisinde kalarak limonu ele alan yazılarında algılarını ortaya çıkaran ifadelerden örnekler aşağıda yer almaktadır:

D: “Kokusu bile ekşidir."

E: "Limonu tadarken çok ekşiydi. Limon en ekşi meyvelerden biridir. Kokusu vardır."

A: "Kokusu var."

U: "Burun, dil ve göz, o duyu organlarımızla anlarız. Yaprak sarma, jelibon gibi çeşitli ürünleri vardır."

E.N. : "Ekşi, yüzümüzü değiştiren." 
Tablo 4. Gül kavramını algılamayla ilgili uygulama öncesi ve sonrasına yönelik bulgular

\begin{tabular}{|c|c|c|c|c|c|}
\hline Duyular & Kod & $f 2.1$ & $f 1.1$ & $f 2.2$ & $f 1.2$ \\
\hline \multirow[t]{3}{*}{ Görme } & Şekli & & & & \\
\hline & Renk & 17 & 13 & 17 & 22 \\
\hline & Dikenli & & & & \\
\hline İşitme & Sesi yok. & 0 & 0 & 0 & 0 \\
\hline \multirow[t]{4}{*}{ Koklama } & Kokmak & 10 & 11 & 8 & 26 \\
\hline & Kolonyası & & & & \\
\hline & Parfümü & & & & \\
\hline & Kremi & & & & \\
\hline \multirow[t]{4}{*}{ Tatma } & Reçeli & 6 & 6 & 1 & 19 \\
\hline & Tatlı & & & & \\
\hline & Tadı yok & & & & \\
\hline & Yenmez & & & & \\
\hline \multirow[t]{2}{*}{ Dokunma } & Yumuşak & 2 & 0 & 3 & 7 \\
\hline & Dikeni batmak & & & & \\
\hline Toplam & & 35 & 30 & 29 & 74 \\
\hline
\end{tabular}

Not. f1.1: deney grubu ön test kod kullanım sıklığı, f1.2: deney grubu son test kod kullanım sıklığı, $f 2.1$ : kontrol grubu ön test kod kullanım sıklığı, f2.2: kontrol grubu son test kod kullanım sıklığı

Tablo 4'te görüldüğü üzere, öğrencilerin gül hakkındaki algıları beş kategori altında toplam on dört koddan oluşmaktadır. Deney grubunda tüm duyulardaki algılamada artış yaşanmıştır $(f 1.2-f$ 1.1=44). En fazla artış görmede yaşanırken artışın yaşanmadığı duyu, işitme duyusu olmuştur.

Kontrol grubunda ise genel toplamda azalma görülmüştür (f2.1- $f 2.2=6)$. Artış sadece dokunmada olurken görme ve işitmede değişim yaşanmamış, koklama ve tatmada azalma görülmüştür.

Deney grubundaki öğrencilerin drama çalışmasının etkisinde kalarak gülü ele alan yazılarında algılarını ortaya çıkaran ifadelerden örnekler aşağıda yer almaktadır:

D: “Dikenleri çok acıtır."

S: "Gülden farklı şeyler yapılabilir."

M: "Gülden birçok ürün elde edebilir."

Y: “Gülle her şey yapılabilir."

A: "Çok yumuşak bir çiçektir." 
Tablo 5. Bardak kavramını algılamayla ilgili uygulama öncesi ve sonrasına yönelik bulgular

\begin{tabular}{|c|c|c|c|c|c|}
\hline Duyular & Kod & $f 2.1$ & $f 1.1$ & $f 2.2$ & $f 1.2$ \\
\hline \multirow[t]{11}{*}{ Görme } & Silindir & & & & \\
\hline & Küçük & 17 & 26 & 21 & 24 \\
\hline & Büyük & & & & \\
\hline & Metal & & & & \\
\hline & Cam & & & & \\
\hline & Plastik & & & & \\
\hline & Seramik & & & & \\
\hline & İçmek & & & & \\
\hline & Kulplu & & & & \\
\hline & Desenli & & & & \\
\hline & Renk & & & & \\
\hline İşitme & Sesi yok. & 0 & 0 & 0 & 0 \\
\hline Koklama & Kokusu yok. & 0 & 2 & 0 & 7 \\
\hline Tatma & Tadı yok. & 1 & 0 & 0 & 4 \\
\hline \multirow[t]{5}{*}{ Dokunma } & Kaygan & 13 & 18 & 9 & 14 \\
\hline & Pürüzsüz & & & & \\
\hline & Sert & & & & \\
\hline & Kırılgan & & & & \\
\hline & Esnek & & & & \\
\hline Toplam & & 31 & 46 & 30 & 49 \\
\hline
\end{tabular}

Not. f1.1: deney grubu ön test kod kullanım sıklığı, $f 1.2$ : deney grubu son test kod kullanım sıklığı, $f 2.1$ : kontrol grubu ön test kod kullanım sıklığı, f2.2: kontrol grubu son test kod kullanım sıklığı

Tablo 5’te görüldüğü üzere öğrencilerin bardak hakkındaki algıları beş kategori altında toplam on dokuz koddan oluşmaktadır. Deney grubunda genel olarak algılamada az miktarda artış yaşanmıştır (f1.2-f1.1=3). En fazla artış koklamada yaşanmıştır. İşitme duyusunda bir değişim ve kazanım olmazken görme ve dokunmada azalma olmuştur.

Kontrol grubunun genel algılama sıklığında az miktarda azalma görülmüştür $(f 2 \cdot 1-f 2 \cdot 2=1)$. Artış sadece görme duyusunda olmuştur. Dokunma ve tatma duyularında azalma görülmüştür. İşitme ve koklamada ise algısal bir bulguya rastlanmamıştır.

Deney grubu öğrencilerinin drama çalışmasının etkisinde kalarak bardağı ele alan yazılarında algılarını ortaya çıkaran ifadelerden örnekler aşağıda yer almaktadır:

M: "Bardağın birçok şekli ve türü vardır." 


\section{Yazma Becerisi Etkinliklerinde Algısal Öğrenme ve Drama İlişkisi}

M: “Karton, demir, plastik, cam bardak vardır."

D: "Etkinlik yapılır, oyun oynanır."

D: "Plastikten oyun olarak kullandık."

Dramanın Yazma Becerisi Etkinliklerinde Yazılı Anlatımı Zenginleştirmeye (benzetme, ilişki kurma, örnek verme, tanımlama ve tasvir etme) Etkisine Yönelik Bulgular

Drama uygulamalarından sonraki yazma etkinliklerinde bazı öğrenciler benzetme, örnek verme, ilişki kurarak anlatma, detaylandırarak anlatma gibi beceri isteyen anlatımlarda bulunmuşlardır. Bazı örnekler aşağıda yer almaktadır:

Zil için;

N: "Şekli kareye benzer."

M: "Bir şeyi haber vermek için kullanılır. Hayatımızı çok kolaylaştırmıştır."

A: "Ses çıkaran bir eşyadır."

E: "Sesi vardır ve sesi çok güzeldir."

Taş için;

U: "Gri ve siyah renkler arası, büyük ve çıkıntılı uçları var."

S: "Gri renklidir, zor kırılır, bazı tarafları sivri, orta boyda, birisinin kafasına gelirse yarabilecek özellikte."

B: "Farklı taş türleri vardır. Örnek: Volkanik taş."

N: "Pürüzlü, sert, ağır, büyük, sivri. Şekli üçgen benzeri."

D: “Kolay kolay kırılmaz."

Limon için;

D: "Şekli armut gibidir. Limona benzer limon tuzu da vardır."

M: "Genellikle şekli ovale benzer."

i: "Limon bir meyvedir. Ağaçlarda yetişir. Bir şekli vardır. Yuvarlak gibidir."

Gül için;

i: "Sarılmış beze benzer."

D: “Onu koklayınca kendimi gül bahçesinde gibi hissederim.”

U: "Kokusu çilek gibi. Şekli ters dönmüş üçgen daire arası." 
Y: "Yumuşacıktır."

N:“Kokusu kolonyaya benzer, yaprakları şişeye benzer .”

A: "Çiçeklerin en güzel kokanıdır."

Bardak için;

Y: "Silindire benzer."

E.N: "içine su doldurulur. Bazıları onu pipetle kullanır."

D: "Bardağın birçok rengi vardır. Şekillerinin hepsi değişiktir. Esnek ve sert türleri vardır. İçinde sıvı içecekler olur."

Örneklerden de anlaşılacağı üzere öğrenciler söz konusu varlıkları kendi algı dünyalarıyla birleştirmişlerdir. Çoğunlukla benzetme edatları kullanarak ilişkilendirmeye çalışmışlardır. Renk, boyut, kütle ile hacim, kullanım alanı ve çeşit yönlerinden örnekler vermişlerdir. Genelleme ve karşılaştırma ifadelerine de yer vermişlerdir.

Dramanın Algısal Öğrenmeyle Birlikte Yazma Becerisi Etkinliklerinde Kullanılan Kelime Sayısına Etkisine Yönelik Bulgular

Tablo 6. Deney ve kontrol gruplarının ön test ve son testteki ortalama kelime sayıları

\begin{tabular}{lllll} 
Kavramlar & O1.1 & 02.1 & 01.2 & 02.2 \\
\hline Zil & 13,03 & 18,32 & 25,96 & 18,12 \\
Taş & 10,11 & 16,60 & 14,30 & 17,68 \\
Limon & 9 & 17,20 & 19,50 & 17,68 \\
Gül & 11,11 & 13,96 & 21,92 & 16,48 \\
Bardak & 7,38 & 16,84 & 15,07 & 15,96 \\
Toplam & 50,63 & 82,92 & 96,75 & 85,92 \\
\hline
\end{tabular}

Tablo 6'da görüldüğü üzere deney grubunun (01) uygulama öncesi ve sonrası yazılı anlatımlarında kullandıkları ortalama kelime sayılarının toplamında anlamlı bir farklılık vardır. Deney grubunun uygulama sonrası yazııı anlatımda kullandıkları kelime sayısı artmıştır $(01.2-01.1=46,12)$. En çok zil, en az ise taş kavramının anlatımında artış olmuştur.

Kontrol grubunun (O2) ortalamalarının toplamına bakıldığında ise üç kelimelik bir artış gerçekleşmiştir. En fazla artış gül kavramında gözlenmiştir.

Bulgular genel olarak incelendiğinde drama ve algısal öğrenme iş birliğinde gerçekleştirilen uygulamalar sonucunda seçili kavramlara yönelik algılama çeşitliliğinde sayısal bir artış olduğu görülmüştür. Yazma becerisi etkinliklerinde algısal öğrenme düzeyinin arttığı gözlenmiştir. Anlatım 
zenginliğini sağlamaya yönelik bulgular incelendiğinde öğrencilerin önceki ifadelerine karşın yazılı anlatımlarında daha çok benzetmeye ve örnek kullanmaya yer verdikleri görülmüştür. Somut olarak karşılaştıkları varlıkları detaylandırdıkları, benzer başka varlıklarla ilişkilendirdikleri saptanmıştır. Varlığın yaygın kullanım alanından uzaklaşıp yeni ve yaratıcı örneklerini sundukları gözlenmiştir. Kullanılan kelime sayısı büyük ölçüde artmıştır. Aynı varlığı daha fazla sözcükle açıklamışlardır. Yapılan araştırma sonucunda, yazma becerisi etkinliklerinde algısal öğrenme ve dramanın önemli bir yerinin olduğu görülmüştür.

\section{Tartışma, Sonuç ve Öneriler}

Araştırma sonucunda, drama yöntemi ile algısal öğrenme arasında yazma becerilerini olumlu yönde etkileyen bir ilişki olduğu görülmüştür. Drama, algısal öğrenme yöntem ve teknikleri ile eğitim öğretimde kullanılan diğer metotlara da yer verdiği için öğrenmenin yüksek bir algılama gücüyle gerçekleşmesini sağlamaktadır (Aytaş, 2013).

Drama, çok duyulu yaşantılar sağlayarak yazılı anlatımda zenginlik yaratır. Birçok araştırma da dramanın yazma becerilerini geliştirdiği sonucunu ortaya koymaktadır (Bağçeci, 2015; Çer, 2017; Kaya Güler, 2008).

Algı odaklı drama uygulamaları sayesinde yazılı anlatımda kullanılan kelime sayısı artmaktadır. Cormack (2003) da yaptığı bir araştırmada dramanın daha uzun hikâyeler yazmayı sağladığı sonucuna ulaşmıştır.

Algının öğrenmenin en temel unsuru olduğu gerçeğinden yola çıkıldığında bireyin algılarını somutlaştırdığında anlama ve anlatma süreçlerinde olumlu değişmelerin olduğu gözlenmiştir. Öncelikle algının bir varsayım olmaktan çıkarak, bireyin onun ne olduğunu, nasıl olduğunu ve her şeyden önce ne işe yaradığını daha somut ve varsayımdan uzaklaştırarak nesnelleştirdiği görülmektedir. Yaptığımız deneysel uygulamalardan çıkardığımız sonuç bize şunları söyletmektedir:

1. Öğrenme sürecinde algıların somutlaştırılmasında uygulama, son derece önemli bir gerekliliktir. Bu gerekliliği en iyi yerine getiren de dramadır.

2. Bir şeyin ne olduğunu teorik olarak anlatmak yerine gözleme ait bütün unsurları ele alıp kullanarak gerçekleştirmek kalıcılığı artırmaktadır. Onun içindir ki algının kalıcılığını yaparak ve yaşayarak gerçekleştirmek mümkün olacaktır.

3. Öğretim sürecinde öğrenilen bilgilerin basamaklaştırılabilmesi için öncelik ve sonralık ilişkisine dikkat etmeli, özellikle edinilen bir kavramın geniş ve dar anlamlarının algılanabilmesi için deneysel uygulamalara yer verilmelidir. Bu da ancak drama ile gerçekleştirilebilmektedir. 
4. Yapılacak eğitim ve öğretim etkinliklerinde drama çalışmaları birden çok duyuya hitap edecek şekilde oluşturulduğunda yazma becerisinde olumlu yönde gelişme sağlanabilecektir.

5. Sınıflarında drama uygulamasına yer veren sınıf ve Türkçe öğretmenleri, öğrencilerin mevcut algılarından yola çıkarak drama yöntemi ile yazma becerilerini geliştirebileceklerdir.

\section{Kaynaklar}

Adıgüzel, Ö. , H. (2006). Yaratıcı drama kavramı, bileşenleri ve aşamaları. Yaratııı Drama Dergisi, 1 (1), 17-29.

Arı, R. (2010). Eğitim psikolojisi. Ankara: Nobel Yayın Dağııım.

Arıkan, Y. (2011). Ilköğretim için uygulamalı tiyatro ve drama eğitimi. İstanbul: Pozitif Yayıncılık.

Aytaş, G. (2008). Türkçe öğretiminde tematik yaratıcı drama etkinlik ve uygulamaları. Ankara: Akçağ Yayıncılık.

Aytaş, G. (2013). Yaratıcı dramanın algısal öğrenmedeki rolü. Ana Dili Eğitimi Dergisi, 1 (1), 101-106.

Aytaş, G. (2016). Türkçe eğitiminde algı. Ankara: Akçağ Yayıncılık.

Bacanlı, H. (2014). Eğitim psikolojisi. Ankara: Pegem Akdemi.

Bağçeci, E. (2015). Developing writing skills through drama in EFL classroom. Muğla: Muğla Sıtkı Koçman Üniversitesi, Yayınlanmamış Yüksek Lisans Tezi. Baltacı, A. (2017). Nitel veri analizinde Miles-Huberman modeli. Ahi Evran Üniversitesi Sosyal Bilimler Enstitüsü Dergisi, 3 (1), 1-15.

Başkale, H. (2016). Nitel araştırmalarda geçerlik, güvenirlik ve örneklem büyüklüğünün belirlenmesi. DEUHFED, $9(1), 23-28$.

Beck, C. , R. (2001). Matching teaching strategies to learning style preferences. The Teacher Educator, 37 (1), 115. doi: $10.1080 / 08878730109555276$

Bowell, P. ve Heap, S. , B. (2001). Planning process drama. London: David Fulton Publishers.

Cormack, R. (2003). Creative drama in the writing process: the impact on elementary students' short stories. Canada: York University, Unpublished Master's Thesis.

Cüceloğlu, D. (2002). Insan ve davranışı. İstanbul: Remzi Kitabevi.

Çer, E. (2017). İlkokul öğrencilerinin yazma becerilerinin geliştirilmesinde yaratııı dramanın etkisi. Eğitim ve Bilim Dergisi, 42 (190), 379-400. doi: 10.15390/EB.2017.7015

Demir, T. (2008). Türkçe eğitimi bölümü öğrencilerinin öğrenme stilleri ve bunların çeşitli değişkenlerle ilişkisi

(Gazi Üniversitesi örneği). Internetten $15 \quad$ Nisan 2018'de http://www.sosyalarastirmalar.com/cilt1/sayi4/sayi4pdf/demir_tazegul.pdf adresinden alınmıştır.

Demiray, K. ve Köker, Ö. (2017). illkokul fen bilimleri ders kitabı. Ankara: Korza Yayıncılık.

Forgus, R. , H. (1966). Perception. United States of America: McGraw-Hill.

İnal, S. , Büyükyavuz, O. ve Tekin, M. (2015). A study on preferred learning styles of Turkish EFL teacher trainees. Australian Journal of Teacher Education, 40 (3), 52-67.

İnceoğlu, M. (2004). Tutum algı iletişim. Ankara: Kesit Tanıtım.

Kaya Güler, i. (2008). Ilköğretim dördüncü sınıf Türkçe dersinde yaratıcı drama yönteminin etkililiği. Samsun: Ondokuz Mayıs Üniversitesi, Yayınlanmamış Yüksek Lisans Tezi.

Nuhoğlu, M. ve Çakmakçı, C. (2007). illköğretim birinci kademede drama ve etkinlikler. Zonguldak: Kök Yayıncılık. 
Nutku, Ö. (1988). Oyun çocuk tiyatro. İstanbul: Özgür Yayıncılık.

Önder, F. (2012). İşbirlikli gruplarda öğrenme stillerinin fizik dersi başarısı ile hatırda tutma düzeyine etkisinin incelenmesi. İzmir: Dokuz Eylül Üniversitesi, Yayınlanmamış Doktora Tezi.

Özgen, E. (2004). Language, learning, and color perception. Current Directions in Psychological Science, 13 (3), 95-98.

Özkan, (2013). İlköğretim öğrencilerinin öğrenme stillerinin çeşitli değişkenler açısından incelenmesi. İstanbul: İstanbul Üniversitesi, Yayınlanmamış Yüksek Lisans Tezi.

Poulsen, J. , C. , S. (1998). Efficacy of drama based teaching on children with learning disabilities. (Doctoral Dissertation). doi: http://dx.doi.org/10.5072/PRISM/20215

Rumney, P. , Buttress, J. ve Kuksa, I. (2016). Seeing, doing, writing: the write here project, 1-11. doi: $10.1177 / 2158244016628590$

Şimşek, Ö. (2007). Marmara öğrenme stilleri ölçeğinin geliştirilmesi ve 9-11 yaş çocuklarının öğrenme stillerinin incelenmesi. İstanbul: Marmara Üniversitesi, Yayınlanmamış Doktora Tezi.

Terry, W. , S. (2012). Öğrenme \& bellek. (Çev. B. Cangöz). Ankara: Anı Yayıncılık.

Ulubey, Ö. ve Toraman, Ç. (2015). Yaratıcı drama yönteminin akademik başarıya etkisi: bir meta-analiz çalışması. Mustafa Kemal Üniversitesi Sosyal Bilimler Enstitüsü Dergisi, 12 (32), 195-220.

Ungan, S. (2007). Yazma becerisinin geliştirilmesi ve önemi. Sosyal Bilimler Enstitüsü Dergisi, 23 (1), 461-472.

Uşaklı, H. (2014). Drama ve iletişim becerileri. Ankara: Nobel Akademi Yayıncılık.

Veznedaroğlu, L. R. ve Oytun Özgür, A. (2005). Öğrenme stilleri: tanımlamalar, modeller ve görevleri. ilköğretim On-line, 4 (2), 1-16.

Yalçın, A. ve Aytaş, G. (2012). Tiyatro ve canlandırma. Ankara: Akçağ Yayıncılık.

\section{Extended Abstract}

Introduction

Learning is a cognitive process that provides permanent behavioral change. We first encounter stimuli before we learn. We sense and understand these stimuli through our sense organs.

The element that starts learning is our perception of what we do with our sense organs. Perception is at the center of all learning. There is a bi-directional relationship between perception and learning. When we combine the perception process with learning, learning becomes faster. Teaching will be more effective when we perform writing activities with perception.

Drama includes activities that can move five senses into action. It is a multi-sensory method that can be used in drama writing activities. Drama is an effective method of learning actively, using techniques such as improvisation and role play. The child who enters into dramatic fiction learns through playful processes. Drama provides freedom to participate. This free environment makes the individual be open to new things. The individual learns in this free environment through his perceptions.

In the literature, there was no study dealing with the relationship between perceptual learning and drama in writing activities. Studies are usually focused on perceptual learning styles.

The main purpose of this study was to reveal the relationship between perceptual learning and drama in writing activities. Increasing the amount of words used, richness of perception, and richness of expression were the sub-purposes of the study.

\section{Method}

The pre-test, post-test and control group, which are most common among the experimental models, were used as a model in this research, which was conducted on two groups selected randomly. The participants were two groups of randomly chosen $3^{\text {rd }}$ graders in an elementary school in Ankara in the 2017-2018 academic year. 51 students ( 25 in the control group, 26 in the experiment group) took part in the experiment. The present research aimed to investigate the relation of perceptual learning and drama in writing skill activities at elementary school.

A dominant entity was chosen for every sense. A total of five items were selected. The selected concepts were bell, stone, lemon, rose, and glass. The perceptions of the students about the bell, stone, lemon, rose and 
glass concepts were intended to be determined. These concepts were chosen from among the concepts that students may have previously encountered. At the same time, attention was paid to the existence of concrete concepts.

Before the study, the students described in writing what these concepts meant for them. In the experiment group, the study was conducted for one hour a week for five weeks. The control group followed the curriculum. The participants were taught by their own classroom teachers. At the end of five weeks, ideas for the same concepts were asked again. Students expressed their thoughts in written form. The pre-test and the post-test lasted one class hour each.

Written narrative paper was used as the data collection tool. The data were analyzed, using content analysis. Commonly used sense expressions were coded in the students' writing. Coded representations were categorized. Two different experts coded the writings separately. The visibility association coefficient of the Miles-Huberman model was used for reliability.

\section{Result and Discussion}

Perception is the key element in learning. When the perceptions of the individual are embodied, positive reflections occur in the processes of understanding and narration.

The results showed that the students wrote about the same concepts, using more words. The concepts were described in terms of analogy, description, and example. The students showed their experience in drama sessions in their writings. Perceptions such as hearing, hearing, smell, tasting, and touching in their habits gave more room to perceptions.

The results showed that writing skills were an important part of perceptual learning and drama. As drama activities in educational and training tasks are designed to appeal to more than one sense, positive development will be achieved in the writing skill.

Language and classroom teachers often have to take part in drama and perceptual learning. They need to use these two practices to improve their writing skills. Education and training activities should be prepared for multiple senses. Thus, positive development in writing skills can be achieved. 